\title{
Detection of clostridial toxins in stools from children with diarrhoea
}

\author{
IDA LUZZI, A. CAPRIOLI*, V. FALBO*, A. GUARINOt, G. CAPANOt, MARIA ALESSIOt, \\ B. MALAMISURAT and PAOLA GIANFRILLI
}

Laboratorio di Batteriologia e Micologia Medica and * Laboratorio di Ultrastrutture, Istituto Superiore di Sanità, Viale Regina Elena 299, 00161 Rome and †/stituto di Pediatria, // Facoltà di Medicina, Università di Napoli, Via Pansini 5, 80131 Naples, Italy

\begin{abstract}
Summary. A cell-culture assay was used to detect toxins directly in stools from sporadic cases of infantile diarrhoea. Cytotoxins were revealed in 11 out of 58 samples from children with diarrhoea, nine of whom had no common enteric pathogens in their stools. A preliminary characterisation of the cytotoxins was obtained by neutralisation tests with clostridial antitoxins.
\end{abstract}

\section{Introduction}

Studies on clostridial toxins have been stimulated recently by the assessment of the role that clostridia can play in intestinal infections (Bartlett et al., 1978; Taylor et al., 1981; Borriello et al., 1984). Direct detection of toxins in stools of patients is now the most rapid, convenient and reliable method for diagnosis of Clostridium perfringens food-poisoning (Giugliano et al., 1983) and C. difficile-associated disease (Chang et al., 1979). The enterotoxin of $C$. perfringens and the cytotoxin of $C$. difficile may be readily detected by cytotoxicity assays in tissue cultures (Chang et al., 1979; Giugliano et al., 1983).

In this study we assessed the possible role of cytotoxin-producing organisms in the aetiology of infantile diarrhoea, which still remains unknown in about half of all cases. A tissue-culture assay was used to detect bacterial toxins directly in stools from sporadic cases of infantile diarrhoea.

\section{Materials and methods}

\section{Subjects}

Fifty-eight children aged $0-3$ years, consecutively admitted to a paediatric hospital in Naples, were examined during 1 year. All patients were admitted because of diarrhoea of various durations and unknown aetiology at the time of study. Stools were collected on admission and examined for the presence of enteric pathogens and for their ability to produce cytotoxic effects in tissue cultures. Stools from 27 asymptomatic children matched by age and season were also collected and examined for cytotoxicity as controls.

Received 1 Jul. 1985; revised version accepted 11 Sep. 1985.

\section{Identification of bacteria}

Enterobacteria (Edwards and Ewing, 1972) and Campylobacter jejuni (Butzler and Skirrow, 1979) were isolated and identified by conventional techniques.

\section{Enterotoxin assays}

Isolates of Escherichia coli were tested for production of heat-labile (Guerrant et al., 1974) and heat-stable (Dean et al., 1972) enterotoxins.

\section{Rotavirus detection}

This was done by an immunoenzymatic assay (Rotazyme; Abbot Laboratories, Chicago, IL, USA).

\section{Cytotoxicity assay}

Stool samples were diluted 1 in 10 in $0.01 \mathrm{M}$ phosphate buffer $(p \mathrm{H} \mathrm{7.4)}$ and faecal extracts obtained by centrifugation (10 000 g for $15 \mathrm{~min}$ ) and filtration of the supernate through $0.45-\mu \mathrm{m}$ membrane filters (Millipore Corp., Bedford, MA, USA). Chinese-hamster ovary (CHO), Vero and HEp2 cells were seeded, at a concentration of $2.5 \times 10^{4}$ cells $/ \mathrm{ml}$ in Eagle's Minimal Essential Medium (Gibco Laboratories, Grand Island, NY, USA) supplemented with fetal calf serum $1 \% \mathrm{v} / \mathrm{v}$, into 96-well microtitration plates $(0.2 \mathrm{ml}$ in each well). Plates were inoculated with two-fold serial dilutions of faecal extracts $(0.02 \mathrm{ml}$ in each well) and scored for cytopathic effects after incubation for $48 \mathrm{~h}$ at $37^{\circ} \mathrm{C}$ in an atmosphere of air containing $\mathrm{CO}_{2} 5 \% \mathrm{v} / \mathrm{v}$. A positive result was recorded when $\geqslant 50 \%$ of the cells in the tissue culture were affected; only faecal samples showing cytotoxicity at a dilution of 1 in 40 were considered positive.

Cytotoxic effects were characterised in preliminary neutralisation tests with three antisera: $C$. difficile antitoxin (kindly provided by Dr T. D. Wilkins, Virginia 
Polytechnic Institute, Blacksburg. VA. USA): antiserum to enterotoxin of $C$. perfringens raised in rabbits by a method previously described by Stark and Duncan (1972): a polyvalent antiserum obtained by pooling monovalent antitoxins to $C$. noryi types $\mathrm{A}$ and $\mathrm{B} . C$. septicum. C. chautoei, C. perfringens types A. B, C. D and E (Wellcome Research Laboratories, Beckenham, Kent). Faecal extracts neutralised by the pool were further tested with the monovalent antitoxins.

\section{Results}

Enteropathogens were isolated from 20 of the 58 children with diarrhoea examined $\left(35_{\%}^{\circ}\right)$; rotavirus alone was found in six, Salmonella serovars in four, Shigella flexneri in three, Camp. jejuni in one; in six cases rotavirus was found as well as pathogenic bacteria (Salmonella serovars in three. Camp. jejuni in two and Yersinia enterocolitica in one).

Eleven of the 58 faecal extracts from cases $\left(19^{\circ}\right.$ ) and two of those from 27 control subjects $\left(7 \cdot 4^{\circ}\right)$ produced cytotoxic effects in at least two of the cell lines tested (table). Nine of the positive samples were from children with diarrhoea from whom enteric pathogens were not isolated.

The cytotoxicity pattern of positive samples and the results of neutralisation tests are shown in the table. The only two positive samples from control subjects and the four from patients that caused rounding of each of the three cell lines tested were neutralised by $C$. difficile antitoxin (table). Seven samples killed HEp2 and Vero cells but not $\mathrm{CHO}$ cells. The cytotoxic effects produced by two of the extracts were neutralised by antiserum to $C$. perfringens enterotoxin. The cytotoxic effects of another three of the samples were neutralised by the pooled clostridial antitoxins; two of these samples, tested further with the nine monovalent antitoxins, were neutralised by monovalent antitoxin to $C$. perfringens type B only. That finding, furthermore, was reproducible. The cytotoxic effects of two faecal extracts from children in whom rotavirus and Camp. jejuni, respectively, had been identified were not neutralised by the antisera available.

\section{Discussion}

With a cytotoxicity assay in tissue cultures, we have detected the presence of clostridial toxins in faecal samples from cases of infantile diarrhoea in which enteric pathogens were not found.

The cytotoxin of $C$. difficile was detected in the faeces of four children, three of whom had been

Table. Cytotoxic effects of faecal extracts for tissue-culture cells and neutralisation by clostridial antitoxins

\begin{tabular}{|c|c|c|c|c|c|c|}
\hline \multirow{3}{*}{$\begin{array}{l}\text { Faecal } \\
\text { sample }\end{array}$} & \multirow{2}{*}{\multicolumn{3}{|c|}{$\begin{array}{l}\text { Cytotoxicity } \\
\text { for cell types }\end{array}$}} & \multicolumn{3}{|c|}{ Neutralisation by } \\
\hline & & & & \multirow{2}{*}{$\begin{array}{l}\text { C. difficile } \\
\text { antitoxin }\end{array}$} & \multirow{2}{*}{$\begin{array}{c}\text { C. perfringens } \\
\text { anti(entero)-toxin }\end{array}$} & \multirow{2}{*}{$\begin{array}{l}\text { Pooled clostridial } \\
\text { gas-gangrene } \\
\text { serum* }\end{array}$} \\
\hline & $\mathrm{HE}$ & Ver & HO & & & \\
\hline \multicolumn{7}{|l|}{ Cases } \\
\hline 1 & $\mathbf{R}$ & $\mathbf{R}$ & $\mathbf{R}$ & + & - & - \\
\hline 2 & $\mathbf{R}$ & $\mathbf{R}$ & $\mathbf{R}$ & + & - & - \\
\hline 3 & $\mathbf{R}$ & $\mathbf{R}$ & $\mathbf{R}$ & + & - & - \\
\hline 4 & $\mathbf{R}$ & $\mathbf{R}$ & $\mathbf{R}$ & + & - & - \\
\hline 5 & K & K & 0 & - & + & - \\
\hline 6 & $\mathbf{K}$ & K & 0 & - & + & - \\
\hline 7 & K & K & o & - & - & + \\
\hline 8 & $\mathbf{K}$ & K & 0 & - & - & + \\
\hline 9 & $\mathbf{K}$ & K & O & - & - & + \\
\hline 10 & K & K & 0 & - & - & - \\
\hline 11 & $\mathbf{K}$ & $\mathbf{K}$ & O & - & - & - \\
\hline \multicolumn{7}{|c|}{ Controls } \\
\hline 1 & $\mathbf{R}$ & $\mathbf{R}$ & $\mathbf{R}$ & + & - & - \\
\hline 2 & $\mathbf{R}$ & $\mathbf{R}$ & $\mathbf{R}$ & + & - & - \\
\hline
\end{tabular}

$+=$ Neutralisation; $-=$ no effect .

$\mathbf{R}=$ rounding of cells; $\mathbf{K}=$ killing of cells; $\mathbf{O}=$ no observed effect.

* This pooled serum contained nine monovalent clostridial antitoxins (see Materials and methods). 
treated with antimicrobials before the onset of the diarrhoea. Because carriage of $C$. difficile and its cytotoxin is not rare in asymptomatic children (Thompson et al., 1983; Torres et al., 1984), it is difficult to assign a causative role for the toxin in symptomatic paediatric patients. It is equally difficult, however, to exclude an aetiological role for $C$. difficile in our patients because of the previous antibiotic treatment and the failure to identify any other pathogen. A close association between disease and toxic factors neutralised by antisera to $C$. perfringens toxins has been shown, these factors being detected only in faeces from children with diarrhoea who had none of the common enteric pathogens present. C. perfringens enterotoxin was found in the faeces of two children, neither of whom had been implicated in food-poisoning episodes, and the cytotoxicity of two faecal samples was neutralised by the monovalent antitoxin to $C$. perfringens

\section{REFERENCES}

Bartlett J G, Chang T W. Gurwith M, Gorbach S L, Onderdonk A B 1978 Antibiotic-associated pseudomembranous colitis due to toxin producing clostridia. New England Journal of Medicine 298:531-534.

Borriello S P, Welch A R, Larson H E, Barclay F, Stringer M F, Bartholomew B A 1984 Enterotoxigenic Clostridium perfringens: a possible cause of antibiotic-associated diarrhoea. Lancet 1:305-307.

Butzler J P, Skirrow M B 1979 Campylobacter enteritis. Clinics in Gastroenterology 8:737-765.

Chang T W, Lauermann M, Bartlett J G 1979 Cytotoxicity assay in antibiotic-associated colitis. Journal of Infectious Diseases 140:765-770.

Dean A G, Ching Y C, Williams R G, Harden L B 1972 Test for Escherichia coli enterotoxin using infant mice: application in a study of diarrhea in children in Honolulu. Journal of Infectious Diseases 125:407-411.

Edwards P R, Ewing W H 1972 Identification of Enterobacteriaceae, 3rd edn. Burgess Publishing Co., Minneapolis.

Giugliano L G, Stringer M F, Drasar B S 1983 Detection of Clostridium perfringens enterotoxin by tissue culture and type B. This was an unexpected finding because the major toxins produced by $C$. perfringens type B should also be neutralised by at least one of the other antisera to the other types of $C$. perfringens (McDonel, 1980). Failure to obtain cross-neutralisation with other specific antisera may suggest the involvement of a toxic factor different from the classical toxins described for $C$. perfringens.

In conclusion, our results suggest that a screening of stools from diarrhoeic children for cytotoxicity might help to improve knowledge of the aetiology of diarrhoeal diseases. In this respect, a further step should be the identification of the organism responsible for cytotoxicity in vivo by its ability to produce the same putative toxin in vitro.

This work was supported in part by grant 83.02916 .52 from Consiglio Nazionale delle Ricerche (Progetto Salute dell'uomo, Controllo delle Malattie Infettive).

double-gel diffusion methods. Journal of Medical Microbiology 16:233-237.

Guerrant R L, Brunton L L, Schnaitman T C, Rebhun L I, Gilman A G 1974 Cyclic adenosine monophosphate and alteration of Chinese hamster ovary cell morphology: a rapid, sensitive in-vitro assay for the enterotoxins of Vibrio cholerae and Escherichia coli. Infection and Immunity 10:320-327.

McDonel J L 1980 Clostridium perfringens toxins (types A, B, C, D, E). Pharmacology and Therapeutics 10:617-655.

Stark R L, Duncan C L 1972 Transient increase in capillary permeability induced by Clostridium perfringens type $\mathrm{A}$ enterotoxin. Infection and Immunity 5:147-150.

Taylor N S, Thorne G M, Bartlett J G 1981 Comparison of two toxins produced by Clostridium difficile. Infection and Immunity 34:1036-1043.

Thompson C M, Gilligan P H, Fisher M C, Long S S 1983 Clostridium difficile cytotoxin in a pediatric population. American Journal of Diseases of Childhood 137:271--274.

Torres J F, Cedillo R, Sanchez J, Dillman C, Giono S, Munoz O 1984 Prevalence of Clostridium difficile and its cytotoxin in infants in Mexico. Journal of Clinical Microbiology 20:274 275 . 